Revista PSICOLOGIA, 2015, Vol. 29 (1), 45-58

\title{
Better off together: A cluster analysis of self-leadership and its relationship to individual innovation in hospital nurses
}

\author{
Catarina Gomes ${ }^{1}$, Luís Curral ${ }^{2}$, António Caetanoํㅜ ${ }^{1}$ Pedro Marques Quinteiro ${ }^{1}$ \\ ${ }^{1}$ Instituto Universitário de Lisboa, BRU-IUL, ISCTE-IUL \\ 2 Faculdade de Psicologia, Universidade de Lisboa
}

\begin{abstract}
Self-leadership is designed to influence positive outcomes like individuals' innovative capacity in the workplace. Nevertheless, research on the relationship between self-leadership and individual innovation has failed to determine which self-leadership strategies contribute to innovation. Thus, this study aims to: explore the existence of different profiles of self-leadership strategies in hospital nurses and, test if these different profiles have different effects on individuals' ability to be innovative. 288 nurses participated in this study. Firstly, data was analysed using Cluster analysis. Secondly, to verify the significance of the association between self-leadership clusters and individual innovation chi-square tests were conducted and the adjusted residuals were considered. Results revealed the existence of 3 different clusters of self-leadership, and that individual innovation is more frequent when all self-leadership strategies are used. The findings suggest that self-leadership strategies vary between individuals and that they all should be fostered in order to promote individual innovation.
\end{abstract}

Keywords: Self-leadership; individual innovation; nurses; health care; cluster analysis.

"É melhor em conjunto": Uma análise de clusters à auto-liderança e a sua relação com a inovação individual em enfermeiros hospitalares: A auto-liderança tem como objetivo o desenvolvimento de resultados positivos como é o caso do desenvolvimento da capacidade de se ser inovador no local de trabalho. Contudo, até ao momento, a investigação sobre a relação entre a auto-liderança e a inovação individual não foi capaz de determinar quais as estratégias de auto-liderança que contribuem para que um individuo seja inovador. Por isto, este estudo tem como objetivos: explorar a existência de diferentes perfis de estratégias de auto-liderança em enfermeiros/as hospitalares e, verificar se estes perfis têm diferentes efeitos sobre a capacidade destes indivíduos serem inovadores. 288 enfermeiros/as participaram neste estudo. Inicialmente, os dados foram analisados por meio de uma análise de Clusters. Seguidamente, e por forma a verificar o significado da associação entre os clusters de auto-liderança e a inovação individual, levaram-se a cabo testes de qui-quadrado e realizou-se uma análise de resíduos ajustados. Os resultados evidenciaram a existência de três clusters de auto-liderança e, que a inovação individual é mais frequente quando todas as estratégias de auto-liderança são utilizadas. Desta forma sugere-se que as estratégias de auto-liderança variam entre os indivíduos e, que todas as estratégias devem ser propagadas a fim de promover a inovação individual.

Palavras-chave: Auto-liderança; inovação individual; enfermeiros/as; cuidados de saúde; análise de clusters.

Innovation is the pillar stone of modern, compassionate and high-quality health care (Borrills, West, Shapiro \& Rees, 2000; Fagnani \& Dumenil, 1976), and it is positively related with individual subjective well-being, and job satisfaction (Do Cho \& Chang, 2008). Furthermore, the promotion of innovative behaviour has been shown to predict patient quality care indexes such as well-being and mortality (West, Borril, Dawson, Scully, Carter, Anelay, Patterson \& Waring, 2011).

Research on innovation in the workplace has found support for the importance of human resources management practices, organizational climate, and individual self-leadership (Curral \& Marques-Quinteiro, 2009; Van de Ven, Polley, Garud, \& Venkataraman, 1999; West, Borrill, Dawson, Brodbeck, Shapiro, \& Haward, 2003). Over 30 years ago, Manz and Sims (1980) introduced into the

${ }^{1}$ Dados para correspondência: Catarina Gomes; Instituto Universitário de Lisboa, BRU-IUL (ISCTE-IUL), Av. a das Forças Armadas, 2W15, 1649-026, Lisboa, Portugal. E-mail: cjvgs@iscte.pt. This study was partially supported by two individual PhD grants from the Portuguese Foundation for Science and Technology (FCT) (SFRH/BD/62603/2009; and SFRH/BD/77614/2011), and a larger project grant (PEstOE/EGE/UI0315/2011). Acknowledgements: We would like to thank SESARAM and Dr. Miguel Ferreira for their support and availability in helping us go through with this study. 
management literature an informal leadership approach that focused on the way people manage and lead themselves - Self-leadership. For many years, primacy had been given to traditional theories of leadership (e.g. directive, transformational), which had been practiced through vertical influence and control (Carmeli, Meitar, \& Weisberg, 2006; Stewart, Courtright \& Manz, 2011). Leadership theories tended to address how leaders create the enabling conditions that allow individuals and groups to do or get done whatever needs to be done (Furtner, Baldegger \& Rauthmann, 2013). This is one reason why the study of leadership focused mainly on leader's traits, qualities, and behaviours (Horner, 1997). However, with Manz and Sims (1980), this focus on formal leadership shifted towards the notion of informal leadership, where individuals are part of a community of practice, where leadership can be shared and distributed among its members (Drath \& Palus, 1994; Pearce \& Conger, 2003). Manz (1986) extended this rationale by proposing that leadership can also be directed towards the self, and that individuals can achieve optimal functioning at work when they exert and lead their own behaviours, thoughts and emotions (Furtner et al., 2013). In this sense, self-leadership can be defined as a process by which individuals control their own behaviour, by means of influencing and leading themselves through the use of specific skills comprised of sets of behavioural and cognitive strategies (Manz, 1986; Neck \& Houghton, 2006).

Since it was introduced, self-leadership has enjoyed an enduring and expanding popularity (Andressen, Konradt \& Neck, 2012; Neck \& Houghton, 2006; Neck \& Manz, 2010; Marques-Quinteiro \& Curral, 2012; Marques-Quinteiro, Curral \& Passos, 2012). However, to the best of our knowledge little is yet known regarding the dynamics that shape the relationship between self-leadership and innovation in the workplace. Previous studies that examined the relationship between self-leadership and individual innovation at work have neglected differences between individuals regarding the use of self-leadership strategies (e.g. Carmeli et al., 2006; Curral \& Quinteiro, 2009; Masood, Shahzad, Nosheen \& Awais, 2011; Pratoom \& Savatsomboon, 2010). Moreover, additional research is needed to further clarify the effectiveness of the self-leadership strategies in improving individual innovation (Masood et al., 2011; Neck \& Houghton, 2006; Pratoom \& Savatsomboon, 2010).

Therefore, the goal of this study is to explore the existence of different profiles regarding the use of self-leadership strategies, and, if these different profiles have distinct effects on the individuals' ability to be innovative in the healthcare sector. Namely, the performance of healthcare systems "depends ultimately on the knowledge, skills and motivation of the people delivering services" (World Health Organization, 2000, p. 77). In particular, nurses are key components in healthcare systems. Nurses play a crucial role throughout their ability to improve patient safety and quality, thus ensuring patients high quality of life outcomes (Aiken, Clarke, Sloane, Lake, \& Cheney, 2008; Needleman, Buerhaus, Mattke, Stewart, \& Zelevinsky, 2002). Furthermore, recent research has shown that leadership and individual innovation in nursing health care are of considerable importance to assure service quality and effective patient health care in hospitals (Clement-O’Brien, Polit \& Fitzpatrick, 2011; Richer, Ritchie \& Marchionni, 2009, Xerri, 2012).

This study contributes to the individual innovation and self-leadership literatures by examining the existence of different profiles regarding the use of self-leadership strategies, and, if these different profiles have distinct effects on the individuals' ability to be innovative in the healthcare sector. This study further contributes to the healthcare literature as it helps to understand which self-leadership strategies should be developed in order to improve innovation in hospitals.

\section{THEORETICAL BACKGROUND AND HYPOTHESES \\ Self-Leadership and Individual Innovation}

Self-leadership is a process that enables individuals to improve their self-motivation and to influence their self-direction throughout the use of a complementary specific set of strategies - behaviour focused strategies, natural reward strategies and constructive thought pattern strategies (Manz, 1986; Neck \& Houghton, 2006; Neck \& Manz, 2010). These strategies operate within broader theoretical frameworks of self-regulation (Carver \& Scheier, 1981; Kanfer, 1970), social-cognition theory (Bandura, 1986) theories of self-control (Mahoney \& Arnkoff, 1979), and self-management (Manz \& Sims, 1980). In a complementary way, these strategies are designed to improve an individual's self-regulation process and effectiveness, thought the improvement of an individual's self-focus, goal setting processes, goal valence and saliency, feedback processes, and task related confidence or performance expectancies (Neck \& Houghton, 2006).

Self-leadership strategies are considered essential in those organizations that need continuous innovation (Pearce \& Manz, 2005). Innovation has progressively been noted in the conceptual and the empirical literature as an important characteristic for an organization's success (e.g. Amabile, 1983; Anderson, De Dreu \& Nijstad, 2004; Hammond, Neff, Farr, Schwall \& Zhao, 2011; West, 2002). Numerous 
definitions of innovation have emerged along the years. In some of these definitions the terms creativity and innovation are used interchangeably (West \& Farr, 1990) or as being part of a broader process that includes both creativity and innovation directed towards implementing change within the work setting (e.g. Rank, Pace \& Frese, 2004; West, 2002). Either way, there is still the need to distinguish between creativity and innovation in applied settings (Anderson, De Dreu \& Nijstad, 2004; Hammond, Neff, Farr, Schwall \& Zhao, 2011; King, 1990; Rank, Pace \& Frese, 2004). Creativity refers to the production, by an individual or a group of individuals working together, of new and useful ideas (Amabile, 1996), and individual innovation is defined as the intentional introduction and application - within one's role - of new and useful ideas, processes, products, or procedures that are relevant and designed to significantly benefit the individual, the group, the organization or the wider society (Farr \& Ford, 1990). In practice, individual innovation starts with the identification of a problem and the generation of ideas or solutions (Scott \& Bruce, 1994). Creativity occurs, as ideation, when individuals have to develop and put into practice ideas that will benefit the organizations, specifically its unit of adoption, in response to a perceived need for innovation (West, Sacramento, \& Fay, 2006). Subsequently, there starts to be a lesser need for creativity when innovation is implemented and adapted to the organizational circumstances (West et al., 2006).

Authors have supported the idea that self-leadership, the combination of a set of strategies, above and beyond the individual strategies alone (Rousseau, 1997), is a positive antecedent of the innovative process (DiLello \& Houghton, 2006; Houghton \& Yoho, 2005; Neck \& Houghton, 2006) understood as a broader process that includes both idea generation and behaviours directed towards implementing change within the work setting (e.g. Hammond et al.; Rank et al., 2004; West, 2002). When individuals are encouraged to lead themselves by being held responsible for making decisions regarding their task (i.e. define and solve problems, and identify opportunities and challenges), self-leading strategies may come to work and boost both creativity (Pearce \& Manz, 2005) and innovation (Hammond et al., 2011) in a complementary self-regulated and effective manner (Neck \& Houghton, 2006).

Recently, the relationship between self-leadership and innovation has been supported by a growing body of evidence that demonstrates how self-leadership positively relates to individual innovation at work (Carmeli et al., 2006; Curral \& Quinteiro, 2009; DiLiello \& Houghton, 2006; Kalyar, 2011; Pratoom \& Savatsomboon, 2010). Specifically, these studies have considered a general dimension of self-leadership (Kalyar, 2011; Pratoom \& Savatsomboon, 2010), the general dimension and its three core categories (Carmeli et al., 2006) and the general dimension and its specific strategies (Curral \& Quinteiro, 2009). However, discrepancies were found on the relationship between self-leadership, core categories and strategies, and individual innovation (Carmeli et al., 2006; Curral \& Quinteiro, 2009), indicating that differences may exist regarding the use of self-leadership strategies between individuals. Following this and considering that self-leadership is a process that is not innate but rather enabled through the learning of complementary self-leadership strategies (Manz, 1986), we propose that: Hypothesis1: Different profiles of use of self-leadership strategies will emerge between nurses.

\section{Self-Leadership's Behaviour-focused strategies and Individual Innovation}

Behaviour-focused strategies are intended to enhance an individual's self-awareness and to foster behavioural management during a task, maximizing behaviour effectiveness, particularly in unpleasant but necessary tasks. Through behaviour-focused strategies, individuals proactively reshape their environment, adjust their behaviour and maximize performance (Neck \& Manz, 2010). These include: self-observation (i.e., the process through which individuals monitor personal behaviour and decide if the behavioural repertoire being used is effective or if it should be changed); self-goal setting (i.e., the ongoing adjustment of professional and personal performance goals to environmental cues); self-reward (i.e., the usage of personal rewards that prompt or inhibit specific behaviours); and self-cueing (i.e., the usage of tools such as memos and pictures to remember things that must be accomplished and must happen after goals have been achieved) (Neck \& Houghton, 2006).

According to Neck and Houghton (2006) self-goal-setting strategies guide and motivate individuals towards the achievement of desired outcomes. Specifically, research on goal setting has demonstrated that when individuals set up to meet difficult and specific goals they tend to increase their effort and have a better performance (Locke \& Latham, 1990). Further, in a longitudinal study regarding the functioning of top management teams, a positive relation between clarity in goal setting and overall team innovation was found (West \& Anderson, 1996). However, it should be noticed that overall team innovation is considered to begin with the individuals capacity to innovate, considering the goal they have to attain, and is dependent on the proportion of innovative individuals that are part of the team (Burningham \& West, 1995; Mumford \& Gustafson, 1988; West \& Anderson, 1996).

Nevertheless, according to Neck and Houghton (2006), goal setting is not enough. When goals are 
set, observation of one's behaviour is needed so that there is the identification of the specific behaviours that have to be changed, enhanced or eliminated in order for the individual to be able to achieve his goals (self-observation). Further, according to the authors, self-reward (intangible or material rewards that promote goal attainment), self-punishment (negative feedback mechanisms that strive behaviours towards goals, by reducing undesired behaviours) and self-cuing (personal guidance strategies that allow individuals not to forget their performance goals) contingencies will then increase the value of goal attainment. Evidence to support these assumptions comes from the field of self-regulation in the academic area. Students that are self-regulated start by setting goals and by selecting and using strategies that make them able to monitor their own performance, (for example through self-observation of one's behaviours), and repeatedly allow themselves to reflect on learning outcomes over a lengthy period of time (for example, through self-judgement - when students compare their performance with what they have to do in order to achieve their goal) (Zimmerman, 2008). Furthermore, in a meta-analysis study, self-regulated learning significantly enhanced students' academic performance and problem solving capacity (Dignath \& Büttner, 2008). Pearce and Manz (2005) argue that defining and solving problems, making decisions, and identifying opportunities and challenges all act as catalysts for creativity, thus stimulating the innovative process (Hammond et al., 2011).

\section{Self-Leadership's Natural reward strategies and Individual Innovation}

Natural reward strategies focus on the positive experience derived from performing a given task or activity, and the process throughout which this task is achieved (Neck \& Houghton, 2006). These strategies create feelings of competence, self-control, and purpose by enhancing intrinsic motivation through task positive modelling (i.e. the exacerbation of positive issues and avoidance of those that are unpleasant through purposefully ignoring them), and suppression of task negative issues (i.e. the proactive transformation of the environment and the nature of the task so that they become more satisfying to accomplish) (Houghton \& Neck, 2002; Neck \& Houghton, 2006; Neck \& Manz, 2010). In support of these assumptions, studies that compared people who were extrinsically motivated to those who were intrinsically motivated for action revealed that the latter had more interest, excitement, and confidence, which would manifest as enhanced performance, persistence and creativity (Deci \& Ryan, 1991; Ryan \& Deci, 2000; Sheldon, Ryan, Rawsthorne, \& Ilardi, 1997). Thus stimulating the innovation process, given that creativity occurs in its early stages as ideation, when individuals are required to develop and implement ideas that will benefit the individual in response to a perceived need for innovation (West et al., 2006).

\section{Self-Leadership's Constructive thought pattern strategies and Individual Innovation}

Finally, constructive thought pattern strategies facilitate the generation of habitual ways of thinking that positively influence performance (Neck \& Manz, 1992). These strategies enable individuals to identify dysfunctional and irrational beliefs and create new thought patterns (Neck \& Manz, 2010) or change existing thoughts into more positive ones (Prussia, Anderson \& Manz, 1998). It includes: evaluating beliefs and assumptions (i.e. the way individuals analyze their values and beliefs in a given momentum and decide either to maintain them or to adjust them to what is expected to be the most effective strategies and thoughts); self-talk (i.e., when individuals engage in self-dialogue as a way to improve thinking processes and rationales); and visualizing successful performance (i.e., the way individuals engage in positive thinking towards the task, personal experience and reality and how they mentally simulate action plans and tasks to be performed (Neck \& Manz, 1992, 1996, 2010; Neck, Neck, Manz, \& Godwin, 1999).

Specifically, Phelan and Young (2003) found that creative self-leadership had a positive relationship with creativity. Creative self-leadership is a reflective internal process that involves three main strategies: (1) cognitive construction of assumptions, beliefs, perceptions and ways of thinking, (2) creative mental imagery that manifests itself through dilemmas involving creative behaviours; and (3) creative self-talk involving internal dialog and feedback that enhance an individual's ability to achieve intended goals. These strategies, similar to the constructive though pattern strategies, intend to create the desired changes, improvements and innovations needed for the individuals to attain the goals that were set, maximizing their performance (Carmeli et al., 2006).

In short, given: (1) the above arguments for the relation of each self-leadership strategy with individual innovation, (2) that the combination of a set of strategies, above and beyond the individual strategies alone (Rousseau, 1997), is a positive antecedent of the innovative process (DiLello \& Houghton, 2006; Houghton \& Yoho, 2005; Neck \& Houghton, 2006) in a complementary self-regulated and effective manner (Neck \& Houghton, 2006) and, (3) that self-leadership is essential to all organizations that are in need of continuous innovation (Pearce \& Manz, 2005) which is the case of healthcare, we suggest the 
following hypothesis:

Hypothesis 2: Nurses who have developed a profile with the combination of all self-leadership strategies will be positively associated with a higher tendency for an individual to be individually innovative.

\section{METHOD}

\section{Procedure and Participants}

After having the consent from the ethics committee, the present data collection took place in a Portuguese public healthcare unit that works in an integrated and complementarity basis and is responsible for providing care to individuals, families and social groups. Participants in this study answered the questionnaire in a voluntary manner. They were fully informed about the aim of the study, and of their surveys' anonymity (they didn't have to identify themselves) and confidentiality (their individual data would not be disclosed).

The sample consisted of 288 nurses who worked at the healthcare unit. 39.9\% worked in medical specialities (e.g. dermatology, paediatrics), 22.2\% worked in surgical specialities (e.g. anaesthesiology, recovery from general surgery) and, $37.8 \%$ worked in mixed specialities, which had medical and surgical components (e.g. obstetrics and gynaecology, ophthalmology). 83\% of them were females. Their ages ranged from 22 to $56(M=35.58 ; S D=9.14)$, and their tenure ranged from a few months of experience to 35 years $(M=8.91 ; S D=6.33)$ of experience.

\section{Measures}

Self-Leadership was assessed using 18 items from the Revised Self-Leadership Questionnaire to the Portuguese Context (Marques-Quinteiro et al., 2012). Participants were asked about the self-leadership behaviours that could be a part of their professional activity. The items reflected the six self-leadership strategies: (1) self-goal setting ( 3 items, e.g. "I establish specific goals for my own performance"), (2) selfreward (3 items, e.g. "When I do an assignment especially well, I like to treat myself to something or activity I especially enjoy")) (3) self-talk ( 3 items, e.g. "Sometimes I talk to myself (out loud or in my head) to work through difficult situations"), (4) visualizing successful performance (3 items, e.g.. "I visualize myself successfully performing a task before I do it"), (5) evaluating beliefs and assumptions ( 3 items, e.g. "I think about my own beliefs and assumptions whenever I encounter a difficult situation")); and (6) natural reward strategies (3 items, e.g. "When I have a choice, I try to do my work in ways that I enjoy rather than just trying to get it over with"). Items were scored on a 7 point scale from 1-Totally disagree to 7-Totally agree. A confirmatory factor analyses carried out to the 18 items revealed that a model of six first order factors, (self-goal setting, self-reward, self-talk, visualizing successful performance, evaluating beliefs and assumptions, natural reward strategies), and two second order factors, (behaviour focused strategies, constructive thought pattern strategies), had a good fit, $\chi^{2}(127)=253.981, p<.001$; RMSEA = $.059 ; \mathrm{CFI}=.947 ; \mathrm{GFI}=.908 ;\left(\chi^{2} / d f=2\right)$, and SRMR $=.110$. All 6 strategies had a good internal consistency, ranging from .70 to .89 .

Individual Innovation was measured using 5 items (West, 1987) translated and adapted to Portuguese (Curral \& Marques-Quinteiro, 2009). Participants were asked to indicate the extent to which they had introduced new and improved ways of doing things at work (e.g. "Introduced new methods to meet work targets?"). Answers were given on a 5 point scale that ranged from $1-$ never to 5 - always. A confirmatory factor analyses carried out to the 5 items revealed a one factor model with a good fit, $\chi^{2}(4)$ $=19.258, \mathrm{p}<.001 ; \mathrm{RMSEA}=.115 ; \mathrm{CFI}=.981 ; \mathrm{GFI}=.972 ; \chi^{2} / d f=4.814$, and SRMR $=.021$. The Cronbach alpha coefficient was .87 .

\section{RESULTS}

\section{Descriptive Results}

Our initial descriptive results of self-leadership strategies indicate that the individuals tend to agree in applying strategies like self-goal-setting $(M=5.92 ; S D=0.9)$, self-talk $(M=5.51 ; S D=1.11)$ and natural reward strategies $(M=5.47 ; S D=0.95)$. Respondents also agree that they applied strategies like selfevaluation of one's values and beliefs $(M=4.93 ; S D=1.06)$, and visualizing successful performance $(M=$ $5.00 ; S D=1.09)$. Self-reward $(M=4.01 ; S D=1.52)$ is a strategy that is more ambiguous as the participants neither agree nor disagree with the application of this kind of strategy.

Finally, individuals indicated that they had sometimes $(M=3.19 ; S D=0.72)$ introduced new methodologies and improved ways of doing things at work.

\section{Cluster Analysis}

For this study a cluster analysis methodology was applied. Cluster analysis allows researchers to determine how many "natural" groups there are in a sample, and further enables them to determine who 
in the sample belongs to which group. Through the use of different algorithms this analysis places objects into groups (clusters) according to well-defined similarity rules. Its aims are to (1) minimize variability within clusters and (2) maximize variability between clusters (Burns \& Burns, 2008; Hair \& Black, 2000).

Hierarchical cluster analysis using Ward's method (Ward, 1963) was used as a first step. It generates a dendrogram for the estimation of the number of likely clusters within the studied sample. The Squared Euclidean Distance was used as an interval measure and all the variables were standardized (Ball \& Hall, 1967; Hair \& Black, 2000).

Regarding the initial hierarchical cluster analysis, the similarity between the dendrogram and the results from Ward's grouping method (Figure 1), showed that a 3 cluster solution was the best solution to explain the data.

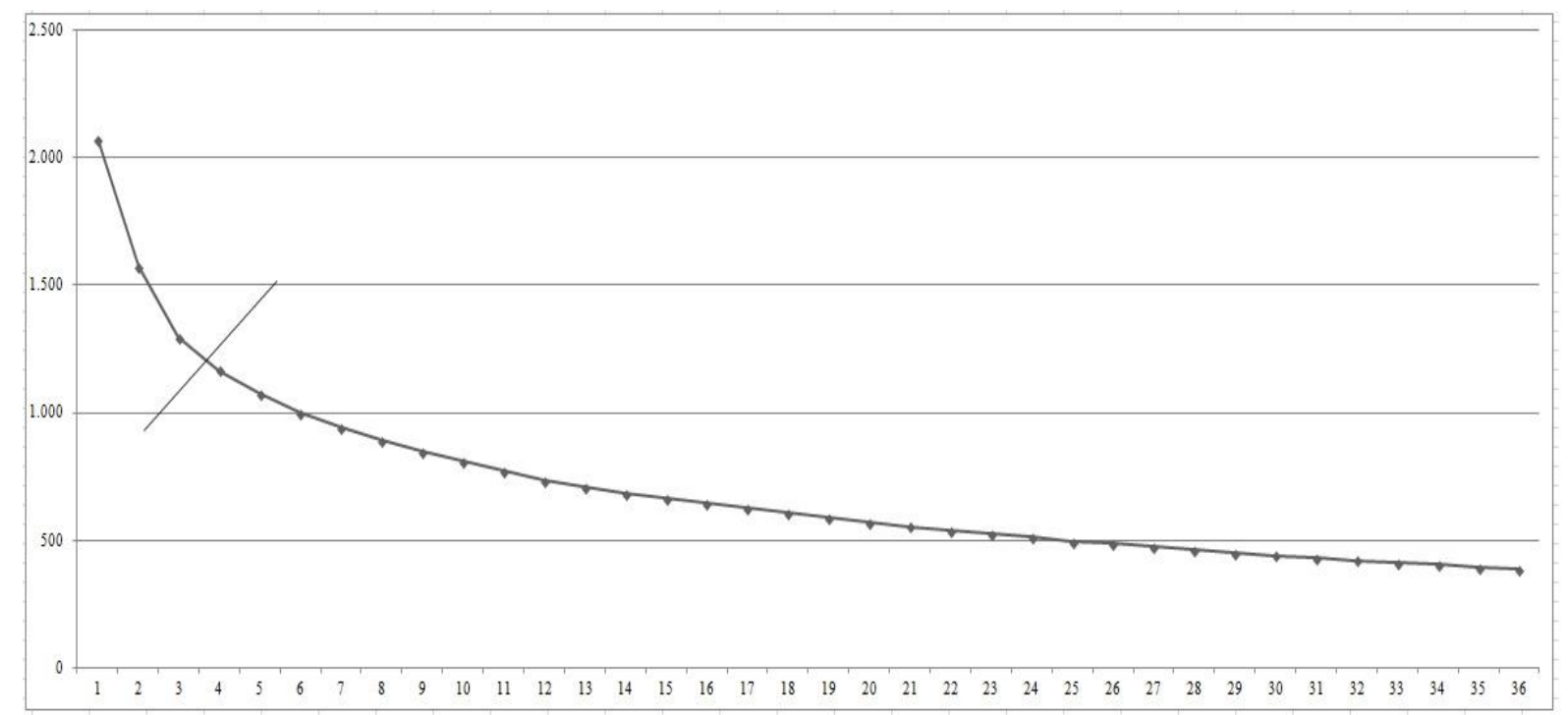

Figure 1. Results from Ward's grouping method.

After estimating the number of clusters, a k-means cluster analysis (Ball \& Hall, 1967; Hair \& Black, 2000) was used as the principal clustering technique.

Table 1 presents the means of the clustering variables, using a k-means cluster analysis, for each of the three clusters, and Figure 2 shows the graphic representation of the different groups' of variables that emerged.

Table 1. Means and standard deviation of the 3 clusters obtained.

\begin{tabular}{|c|c|c|c|c|c|c|c|c|c|c|c|c|}
\hline \multirow{2}{*}{ Clusters } & \multicolumn{2}{|c|}{ SGS } & \multicolumn{2}{|c|}{ SR } & \multicolumn{2}{|c|}{ ST } & \multicolumn{2}{|c|}{ VSP } & \multicolumn{2}{|c|}{ EVB } & \multicolumn{2}{|c|}{ NRS } \\
\hline & $M$ & $S D$ & $M$ & $S D$ & $M$ & $S D$ & $M$ & $S D$ & $M$ & $S D$ & $M$ & $S D$ \\
\hline 1 & 5.82 & .67 & 3.951 & .97 & 5.59 & .83 & 5.11 & .85 & 4.90 & .82 & 5.49 & .73 \\
\hline 2 & 6.29 & .44 & 5.748 & .81 & 6.15 & .75 & 5.80 & .65 & 5.86 & .62 & 6.20 & .57 \\
\hline 3 & 5.76 & .82 & 2.319 & .85 & 4.70 & 1.38 & 3.94 & 1.07 & 4.00 & 1.03 & 4.66 & 1.04 \\
\hline
\end{tabular}

Note. SGS = Self Goal Setting; SR= Self Reward; ST= Self Talk; VSP= Visualizing Successful Performance; EVB= Evaluating Beliefs and Assumptions; NRS= Natural Reward Strategies

Significant differences between clusters can be tested with ANOVAs. By conducting a one-way ANOVA it can be determined which strategies are significantly different between clusters (Burns \& Burns, 2008).

Statistically significant differences were found between strategies of each cluster as determined by the one-way ANOVAs at the $p<.05$ level. Specifically, self-goal setting, $F(2,285)=15.19, p<.001$, selfreward, $F(2,285)=262.18, p<.001$, self-talk, $F(2,285)=40.76, p<.001$, visualizing successful performance, $F(2,285)=85.65, p<.001$, evaluating beliefs and assumptions, $F(2,285)=91.03, p<.001$, and natural reward strategies, $F(2,285)=69.77, p<.001$.

Post hoc comparisons using Tukey's HSD test (Table 2) indicated that the mean scores of all strategies where significantly different between clusters, except for self-goal setting between cluster $1(M$ $=5.82, S D=.67)$ and cluster $3(M=5.76, S D=.82)(p=.780)$. 
Gomes, Curral, Caetano e Quinteiro

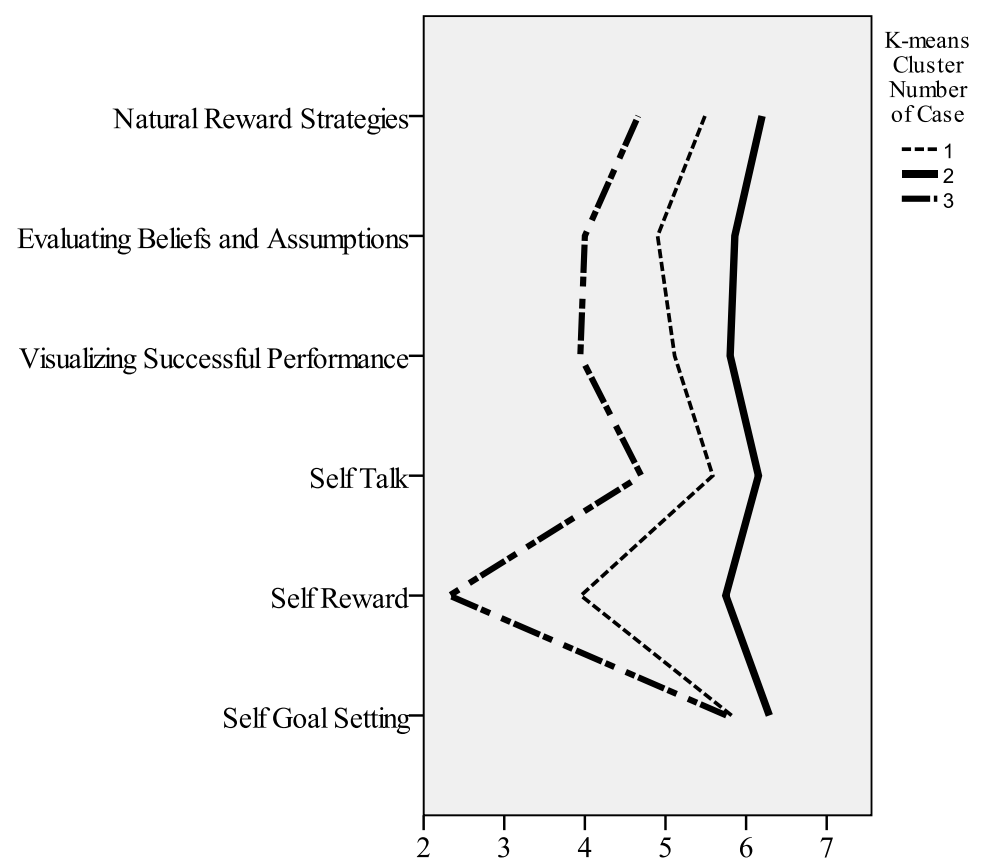

Figure 2. Graphic representation of the three cluster solution.

Table 2. Post hoc test - Tukey test - mean difference (I-J), standard deviation and significance.

\begin{tabular}{|c|c|c|c|c|c|c|c|c|}
\hline & & & & & Strate & & & \\
\hline & & & & & $S$ & & & \\
\hline & & & $\Delta \mathrm{M}$ & SD & $\Delta \mathrm{M}$ & SD & $\Delta \mathrm{M}$ & SD \\
\hline & & Cluster 1 & -- & -- & $-.468^{*}$ & .095 & .065 & .096 \\
\hline & SGS & Cluster 2 & $.468^{*}$ & .095 & -- & -- & $.532^{*}$ & .110 \\
\hline & & Cluster 3 & -.065 & .096 & $-.532^{*}$ & .110 & -- & -- \\
\hline & & & & & $\mathrm{S}$ & & & \\
\hline & & & & & & & & \\
\hline & & & $\Delta \mathrm{M}$ & $\mathrm{SD}$ & $\Delta \mathrm{M}$ & SD & $\Delta \mathrm{M}$ & SD \\
\hline & & Cluster 1 & -- & -- & $-1.797^{*}$ & .129 & $1.632^{*}$ & .131 \\
\hline & SR & Cluster 2 & $1.797^{*}$ & .129 & -- & -- & $3.428^{*}$ & .150 \\
\hline & & Cluster 3 & $-1.632^{*}$ & .131 & $-3.428^{*}$ & .150 & -- & -- \\
\hline & & & & & S & & & \\
\hline & & & & & & & & \\
\hline & & & $\Delta \mathrm{M}$ & $\mathrm{SD}$ & $\Delta \mathrm{M}$ & SD & $\Delta \mathrm{M}$ & SD \\
\hline & & Cluster 1 & -- & -- & $-.567^{*}$ & .140 & $.887^{*}$ & .142 \\
\hline & ST & Cluster 2 & $.567^{*}$ & .140 & -- & -- & $1.453^{*}$ & .163 \\
\hline & & Cluster 3 & $-.887^{*}$ & .142 & $-1.454^{*}$ & .163 & -- & -- \\
\hline & & & & & $\mathbf{V}$ & & & \\
\hline Strategies (I) & & & & & & & & \\
\hline & & & $\Delta \mathrm{M}$ & SD & $\Delta \mathrm{M}$ & SD & $\Delta \mathrm{M}$ & SD \\
\hline & & Cluster 1 & -- & -- & $-.689^{*}$ & .124 & $1.170^{*}$ & .126 \\
\hline & VSP & Cluster 2 & $.689^{*}$ & .124 & -- & -- & $1.857^{*}$ & .144 \\
\hline & & Cluster 3 & $-1.170^{*}$ & .126 & $-1.857^{*}$ & .144 & -- & -- \\
\hline & & & & & $\mathbf{E}$ & & & \\
\hline & & & & & & & & \\
\hline & & & $\Delta \mathrm{M}$ & SD & $\Delta \mathrm{M}$ & SD & $\Delta \mathrm{M}$ & SD \\
\hline & & Cluster 1 & -- & -- & $-.958^{*}$ & .119 & $-.902^{*}$ & .121 \\
\hline & EVB & Cluster 2 & $.958^{*}$ & .119 & -- & -- & $1.860^{*}$ & .138 \\
\hline & & Cluster 3 & $-.902^{*}$ & .121 & $-1.860^{*}$ & .138 & -- & -- \\
\hline & & & & & $\mathrm{N}$ & & & \\
\hline & & & & & & & & \\
\hline & & & $\Delta \mathrm{M}$ & SD & $\Delta \mathrm{M}$ & SD & $\Delta \mathrm{M}$ & SD \\
\hline & & Cluster 1 & -- & -- & $-.709^{*}$ & .112 & $.828^{*}$ & .114 \\
\hline & NRS & Cluster 2 & $.709^{*}$ & .112 & -- & -- & $1.536^{*}$ & .130 \\
\hline & & Cluster 3 & $-.828^{*}$ & .114 & $-1.536^{*}$ & .130 & -- & -- \\
\hline
\end{tabular}

Note. SGS = Self Goal Setting; SR= Self Reward; ST= Self Talk; VSP= Visualizing Successful Performance; EVB= Evaluating Beliefs and Assumptions; NRS= Natural Reward Strategies 
Cluster 1 includes individuals who use all of the strategies except for self-reward. This cluster can be described as self-leaders who don't increase extrinsic self-motivational value in their goals. Cluster 2 includes professionals who use all of the self-leadership strategies and can be denominated as complete self-leaders. Cluster 3 comprises individuals who only use one strategy from each of the three dimensions of self-leadership (i.e. self-goal-setting, natural rewards strategies and self-talk). This cluster can be described as self-leaders who focus mainly on the task they have to meet. These results support hypothesis 1.

\section{Chi-Square Analysis}

The derivation of clusters was followed by statistical comparisons for the variables used in clustering. In order to test if there was a significant relationship between the self-leadership clusters obtained and the extent to which individuals had introduced new and improved ways of doing things at work, a chi-square analysis was conducted. For this, individual innovation was considered as an additional "external" variable. In this step this variable was considered to be an ordinal variable. Due to the very small number of individuals that answered never and almost never to the individual innovation scale items, it was recoded to range from 1-never/rarely to 4-always,

Table 3 presents the chi-square tests of the relation between individual innovation and the 3 clusters obtained. The association between individual innovation and the 3 clusters was significant $\left(\chi^{2}=\right.$ 12.54; $p=.05$ ).

Table 3. Chi-square tests of the relation between individual innovation and the 3 clusters.

\begin{tabular}{|c|c|c|c|c|c|c|c|c|c|c|}
\hline & & \multicolumn{6}{|c|}{ K-means Cluster } & \multirow{3}{*}{$\chi^{2}$} & \multirow{3}{*}{$d f$} & \multirow{3}{*}{ Sig. } \\
\hline & & \multicolumn{2}{|c|}{1} & \multicolumn{2}{|c|}{2} & \multicolumn{2}{|c|}{3} & & & \\
\hline & & $n$ & $\%$ & $n$ & $\%$ & $n$ & $\%$ & & & \\
\hline \multirow{5}{*}{$\begin{array}{l}\text { Individual } \\
\text { Innovation }\end{array}$} & Rarely & 24 & 16.8 & 10 & 13.5 & 8 & 11.3 & & & \\
\hline & Sometimes & 83 & 58.0 & 38 & 51.4 & 48 & 67.6 & & & \\
\hline & Almost always & 31 & 21.7 & 17 & 23.0 & 14 & 19.7 & 12.54 & 6 & $.05^{*}$ \\
\hline & Always & 5 & 3.5 & 9 & 12.2 & 1 & 1.4 & & & \\
\hline & Total & 143 & 100 & 74 & 100 & 71 & 100 & & & \\
\hline
\end{tabular}

Note. Significant for $p \leq .05$

\section{Adjusted Residuals Analysis}

Given that the overall chi-square was significant, the adjusted residuals (non-parametric equivalent of zscores) for the cell percentage of each subgroup were examined. Adjusted residuals determine if the behaviours under study occur significantly more or less often than expected. An adjusted residual score greater than 1.96 or lower than -1.96 for a given subgroup percentage indicates that the subgroup differs significantly $(p<0.05)$ from the overall group percentage. In other words, a value above 1.96 means the behaviours occur significantly more often, and a value below -1.96 less often (Bakeman \& Quera, 1995).

It can be seen in Table 4 that the individuals were more prone to introduce new and improved ways of doing things at work when they used all the self-leadership strategies $(12.2 \%$; adjusted residual = 3.1), in other words when they were "complete self-leaders". This result supported hypothesis 2.

Table 4. Adjusted residuals of the relation between the 3 clusters and Individual Innovation.

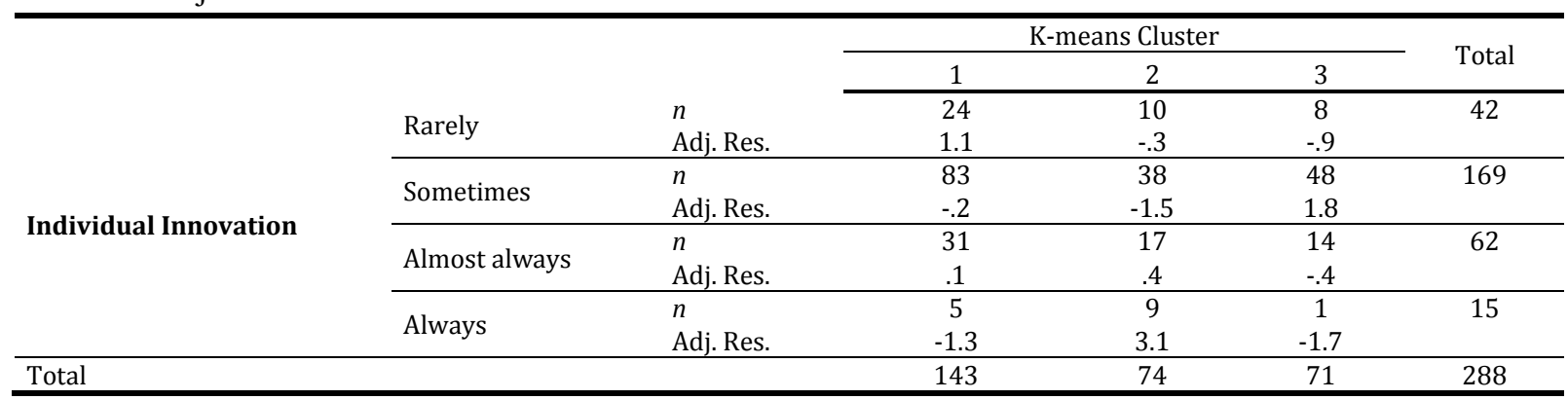

\section{DISCUSSION}

In this study we tested for the existence of different profiles of self-leadership strategies and sought to uncover their association with individual innovation in the healthcare context. In this way, our study contributed to the growing body of literature on self-leadership, and further added to the clarification of the relation between self-leadership strategies and individual innovation. As hypothesized, different configurations of self-leading strategies were found to be used by individuals. Furthermore, results indicated that individual innovation is more frequent when individuals use self-leadership as a whole set 
of strategies, rather than when they use different configurations of self-leading strategies.

Our findings point out to the existence of different profiles of self-leadership strategies. In our analyses three profiles were identified and although two of the profiles differ only in the use of selfrewards strategies, considerable differences emerged in the third profile. Individuals in the "self-leaders who focus mainly on the task they have to meet" profile mainly relied on one of the strategies of the three main dimensions of self-leadership (i.e. self-goal-setting, self-talk and natural reward strategies). This finding is in line with Manz (1986), and adds evidence to his argument that self-leadership is a learned behaviour. The emergence of different profiles of self-leadership strategies indicates that there are differences regarding which self-leadership strategies have been learned by the individuals. While other studies have considered general self-leadership and its three main dimensions (e.g. Carmeli et al., 2006; Curral \& Quinteiro, 2009; DiLiello \& Houghton, 2006; Kalyar, 2011; Pratoom \& Savatsomboon, 2010) without clarifying which strategies had been learned, this study adds evidence by revealing that different combinations of learned strategies do emerge between individuals.

Our results also indicate that in the overall the most applied strategy among the three profiles is self-goal-setting. An explanation for this is that the Portuguese public administration integrated performance evaluation system (SIADAP) comprises self-goal setting as a critical criterion to be evaluated upon. This system is based on an annual management design for public administration services centred upon objectives and, for universal application throughout state, regional and local administration. As professionals are required to set personal goals regarding their own performance they will naturally report higher self-goal-setting behaviours. In support of this explanation Neck and Manz (1996b) suggest that when goals are set in an organizational setting, (under the organizations rules, policies and procedures), they might be assumed by the individuals as self-regulatory organizational standards. In other words, by requiring the employees to set goals, the organization tends to have more influence over the self-regulatory process of their employees than the employees themselves. Although this result may indicate that an external organizational influence exists, it also provides evidence to strengthen Manz (1986) argument that self-leadership is a learned behaviour, given that individuals are asked to set goals for their performance. In this specific nursing context this can be accounted as learning, due to exposure to organizational procedures (Poell \& Van der Krogt, 2014).

In addition, compared to all the other self-leading strategies, self-reward seemed to be the less used strategy. In line with the previous explanation for goal setting, this may also be because the Portuguese public administration integrated performance evaluation system (SIADAP) already has an embedded reward system. Again, the organization may have more influence over the self-regulatory process (Neck \& Manz, 1996b) however, in this case, leading the individuals to reduce their intentions of perceived necessity for self-reward. From this, it can be suggested that the lack of self-leadership strategies contributes for the organizational standards to have more influence over the individuals' selfregulatory process. In other words, given that self-leadership strategies act in a complementary way in order to improve individuals' self-regulatory ability (Neck \& Houghton, 2006), the lack of self-leadership strategies in an organizational setting, may lead an individual to be more externally influenced and less internally influenced, which in the long run might have its consequences in terms of an individual's selfregulatory effectiveness. Following this, this result also points to the importance of external contingencies in enhancing an individual's self-regulatory effectiveness. For example, and in line with Neck \& Houghton (2006), given a task that is not intrinsically motivating or naturally rewarding, external self-reward contingencies may become particularly appropriate and effective. They increase the value of goal achievement, in that way leading to an enhanced effort and determination toward goal attainment. In this way our study adds to previous research on motivation (e.g. Deci \& Ryan, 1985; Deci \& Ryan, 1991; Deci, Eghrari, Patrick, \& Leone, 1994) by accounting, not only for the importance of intrinsic motivation (natural rewards), but also for the importance of external motivation (self-reward), in helping individuals set and manage self-regulatory standards, by cognitively considering what should be done, how it should be done and why it should be done, which will improve their self-regulatory effectiveness and increase their degree of internal influence. Furthermore, this finding adds to Toode, Routasalo and Suominen (2011) argument, that motivation to work among nurses is created throughout the process of individual cognition and consciousness of the different situations, while at the same time taking into consideration the correspondence between both internal and external factors and their impact upon those situations.

The findings from this study help to further clarify the relationship between self-leadership and individual innovation (e.g. Curral \& Quinteiro, 2009; Neck \& Houghton, 2006; Pratoom \& Savatsomboon, 2010). The results indicate that individual innovation is more frequent when individuals use selfleadership as a whole set of strategies, rather than when they assume a profile that is in lack of selfleadership strategies, as it is the case of profiles 1 ("self-leaders who don't increase value in their goals") and 3 ("self-leaders who focus only on internalizing the goal they have to meet"). Given these differences 
between clusters, just the lack of self-reward seems to be critical for not engaging in individual innovation. This finding lends support to the argument that the combination of all self-leadership strategies, in a complementary self-regulated manner (Neck \& Houghton, 2006), is a positive antecedent of innovation (DiLello \& Houghton, 2006; Houghton \& Yoho, 2005; Neck \& Houghton, 2006). An explanation for this, is that, in an organizational setting, when used all together these strategies enhance individual self-regulatory effectiveness by increasing the degree of internal influence upon self-regulatory standards (Neck \& Houghton, 2006) in this particular case, these strategies may increase an individuals' self-regulatory functioning towards innovating in the health sector. In line with this explanation, and given that all innovation is change (West \& Farr, 1990), Unsworth and Mason (2012) findings show that self-leadership provides individuals with a combination of behavioural, cognitive and emotional strategies that are effective in environments subject to change. Furthermore, contrary to other studies in the healthcare sector (e.g. West \& Anderson, 1996), these findings expand and support the notion that goal setting on its own is not a sufficient strategy to guarantee individual innovation, reinforcing Neck and Houghton (2006) assumptions that other strategies are necessary for individuals to be innovative. Moreover, they expand on goal setting theory (Locke \& Latham, 1990), demonstrating not only the importance of goals but also the importance of this set of strategies in predicting performance at work, given that individual innovation is known to facilitate performance (Carmeli et al., 2006; Curral \& Quinteiro, 2009; DiLiello \& Houghton, 2006; Smith, 2002).

\section{Practical Implications}

From a practical point of view, our findings can be applied to strengthen nursing staff in at least two ways.

First, results indicated the existence of different profiles of self-leadership strategies. Organizations would benefit if they took into account the different profiles that may emerge within their employees, for example, during the selection process for "the right man for the right job". In particular healthcare organizations would benefit from this given that the organization's functioning is dependent on the knowledge, skills and motivation of its professionals' to provide better care for patients (World Health Organization, 2000). Self-leadership strategies, in a complementary way, allow for the improvement of the nurses self-regulatory ability to manage their organizational standards by increasing their degree of internal influence, upon their knowledge, skills and motivation, which in turn enhances their individual effectiveness (Neck \& Houghton, 2006). In sum, if healthcare units intend to hire individuals it would be worthwhile to consider their self-leadership profiles.

Second, considering that individual innovation is known to facilitate both organizational performance and long term success (Carmeli et al., 2006; Curral \& Quinteiro, 2009; DiLiello \& Houghton, 2006; Smith, 2002) in a competitive and knowledge based society (Carmeli et al., 2006), and given that self-leadership is conceptualized as a learned behaviour rather than a fixed trait (Manz, 1986), organizations willing to foster innovation would benefit from administering self-leadership training to their workforce. Differences between clusters suggest that training programs aimed at fostering individual innovation would benefit from having all self-leadership strategies considered, instead of only considering the use of some of the strategies. In support of this idea, Unsworth and Mason (2012) in a longitudinal study found support for the proposition that self-leadership training provided participants with a "treatment package" (all self-leadership strategies) that was more beneficial than only training in particular components (e.g. goal setting). Hence, organizations need to invest on the development of their employees' right set of self-leadership strategies, in order to improve their self-regulatory ability that in consequence might lead to the overall improvement of an organization's functioning. Specifically, healthcare organizations would benefit from training programs in self-leadership given that nurses work in a knowledge intensive and extremely professionalized sector, with constant demands for innovation focused on better quality of life improvements, the introduction of new health procedures, (e.g. vaccination) and health technologies (e.g. microfluidics, needle-free diabetes care).

\section{Limitations and Future Research Directions}

This study has some limitations. First, the sample refers to a specific professional group, which implies that generalizations should be made with caution. Second, all measures were collected through single respondents' method, which means that the results can't be interpreted as causal. Third, all the data was collected at a specific point in time using a cross sectional design. Although these limitations may cause common method biasing, several authors have not only found no significant differences between self and supervisor ratings (Bakker, Demerouti \& Verbeke, 2004; Shalley, Gilson \& Blum, 2009), as also suggest that common-method biasing is not an omnipresent phenomenon whenever measures are obtained through single respondents (Brannick, Chan, Conway, Lance \& Spector, 2010). We cannot rule out that the 
effect of common variance contributed to so some extent to the studied relation, however, Harman's onefactor test, including all items from all the constructs, revealed a seven factor solution with eigenvalue greater than 1.0, rather than a single factor. The seven factor solution accounted for $73 \%$ of the total variance, and the first factor did not account for the majority of the variance $(27 \%)$. Hence, it seems that common method variance did not influence our results in a significant manner. Fourth, the Portuguese version of the revised self-leadership questionnaire (Marques-Quinteiro et al., 2012) relates to seven of the original strategies of the revised self-leadership questionnaire (Houghton \& Neck, 2002). As Alves, Lovelace, Manz, Matsypura, Toyasaki, and Ke (2006) have argued self-leadership has different aspects across nations. Based on Hofstede's work, these authors have argued that self-leadership strategies should also be differently used across nations because different cultures value different attributes and practices. In the particular case of self-observation, and its theoretical importance for self-regulation, (Marques-Quinteiro et al., 2012) the GLOBE project results for the Latin cluster indicate that the Portuguese culture scores high regarding power distance and coordinate work effort (Jesuíno, 2002). This result indicates that individuals self-monitoring activity is avoidable because they don't have to be aware of the task situation.

Given these limitations, future research would benefit from the incorporation of some changes. In this sense, future studies should consider other professional groups, longitudinal settings and multisource data in order to: (1) increase the study's reliability, (2) avoid over-reporting and (3) control for the influence of common method bias. Furthermore, the replication of this study considering these changes will allow researchers: (1) to verify if there are any configurational changes regarding the selfleadership profiles and (2) to extend research by further studying what promotes or inhibits these changes.

\section{Concluding Remarks}

In conclusion, our research provided some valuable contributions to the study of the links between leadership and individual innovation in health care. The current study expands upon previous studies on self-leadership by demonstrating that self-leadership differs between individuals, and that it is a key component for professionals to engage in individual innovation when used as a complete and complementary set of strategies. Academics and professionals may benefit from this work as it leads to helpful insights on health care quality of life. Specifically, the development of research towards the understanding of the relationship between self-leadership and individual innovation in the work place may lead to improvements regarding health care quality of life through the use of adequate human resources practices.

\section{References}

Aiken, L., Clarke, S. P., Sloane, D. M., Lake, E. T., \& Cheney, T. (2008). Effects of hospital care environment on patient mortality and nurse outcome. Journal of Nursing Administration, 38, 223-229.

Alves, J. C., Lovelace, K. J., Manz, C. C., Matsypura, D., Toyasaki, F., \& Ke, K. G. (2006). A cross-cultural perspective of self-leadership. Journal of Managerial Psychology, 21, 338-359.

Amabile, T. M. (1983). The social psychology of creativity. New York: Springer-Verlag.

Amabile, T. M. (1996). Creativity in context. Boulder: Westview Press.

Anderson, N., De Dreu, C. K., \& Nijstad, B. A. (2004). The routinization of innovation research: A constructively critical review of the state-of-the-science. Journal of Organizational Behavior, 25(2), 147-173.

Andressen, P., Konradt, U., \& Neck, C. P. (2012). The relation between self-leadership and transformational leadership: Competing models and the moderating role of virtuality. Journal of Leadership \& Organizational Studies, 19, 68-82.

Bakeman, R., \& Quera, V. (1995). Analyzing interaction: Sequential analysis with SDIS and GSEQ. New York: Cambridge University Press.

Bakker, A. B., Demerouti, A., \& Verbeke, W. (2004). Using the job resources-demand model to predict burnout and performance. Human Resource Management, 43, 83-104.

Ball, G. H., \& Hall, D. J. (1967). A clustering technique for summarizing multivariate data. Behavioural Science, 12, 153-155.

Bandura, A. (1986). Social foundations of thought and action: A social cognitive theory. Englewood, Cliffs, NJ: Prentice Hall.

Borrils, C., West, M., Shapiro, D., \& Rees, A. (2000). Team working and effectiveness in health care. British Journal of Health Care Management, 6, 364-371.

Brannick, M. T., Chan, D., Conway, J. M., Lance, C. E., \& Spector, P. E. (2010). What is method variance and how can we cope with it? A panel discussion. Organizational Research Methods, 13, 407-420. 
Burningham, C., \& West, M. A. (1995). Individual, climate and group interaction processes as predictors of work team innovation. Small Group Research, 26, 106-117.

Burns, R. P., \& Burns, R. (2008). Business research methods and statistics using SPSS. London: Sage.

Carmeli, A., Meitar, R., \& Weisberg, J. (2006). Self-Leadership skills and abilities. International Journal of ManPower, 27, 75-90.

Carver, C. S., \& Scheier, M. F. (1981). Attention and self-regulation: A control-theory approach to human behaviour. New York: Springer-Verlag.

Cho, S. D., \& Chang, D. R. (2008). Salesperson's innovation resistance and job satisfaction in intraorganizational diffusion of sales force automation technologies: the case of South Korea. Industrial Marketing Management, 37, 841-847.

Clement-O’Brien, K. Polit, D. F., \& Fitzpatrick, J. J. (2011). Innovativeness of nurse leaders. Journal of Nursing Management, 19, 431-438.

Curral, L., \& Marques-Quinteiro, P. (2009). Self-leadership and work role innovation: Testing a mediation model with goal orientation and intrinsic motivation. Revista de Psicologia del Trabajo y de las Organizaciones, 25(2), 163-174.

Deci, E. L., \& Ryan, R. M. (1985). Intrinsic motivation and self-determination in human behaviour. New York: Plenum.

Deci, E. L., \& Ryan, R. M. (1991). A motivational approach to self: Integration in personality. In R. Dienstbier (Ed.), Nebraska Symposium on Motivation: Perspectives on Motivation (Vol.38, pp. 237288). Lincoln: University of Nebraska.

Press. Deci, E. L., Eghrari, H., Patrick, B. C., \& Leone, D. R. (1994). Facilitating internalization: The selfdetermination theory perspective. Journal of Personality, 62, 119-142.

Dignath, C., \& Büttner, G. (2008). Components of fostering self-regulated learning among students. A meta-analysis on intervention studies at primary and secondary school level. Metacognition and Learning, 3, 231-264.

DiLiello, T. C., \& Houghton, J. D. (2006). Maximizing leadership capacity for the future: Toward a model of Self-Leadership, Innovation and Creativity. Journal of Managerial Psychology, 21, 319-337.

Drath, W. H., \& Palus, C. J. (1994). Making common sense: Leadership as meaning-making in a community of practice. Greensboro, NC: Center for Creative Leadership.

Fagnani, F., \& Dumenil, G. (1976). Health indicators or health system analysis? Extracts from a french survey. Social Indicators Research, 3, 37-74.

Farr, J. \& C. Ford (1990). Individual innovation. In M. A. West \& J. L. Farr (Eds.), Innovation and Creativity at Work: Psychological and Organisational Strategies (pp. 63-80). Chichester: John Wiley.

Furtner, M. R., Baldegger, U., \& Rauthmann, J. F. (2013). Leading yourself and leading others: Linking selfleadership to transformational, transactional, and laissez-faire leadership. European Journal of Work and Organizational Psychology, 22, 436-449.

Hair, J. F., \& Black, W. C. (2000). Cluster analysis. In L. G. Grimm, \& P. R. Yarnold (Eds.), Reading and understanding more multivariate statistics (pp. 147-205). Washington, DC: American Psychology Association.

Hammond, M. M., Neff, N. L., Farr, J. L., Schwall, A. R., \& Zhao, X. (2011). Predictors of individual-level innovation at work: A meta-analysis. Psychology of Aesthetics, Creativity, and the Arts, 5, 90-105.

Horner, M. (1997). Leadership theory: past, present and future. Team Performance Management, 3, 270-87.

Houghton, J. D., \& Neck, C. P. (2002). The revised self-leadership questionnaire: Testing a hierarchical factor structure for Self-Leadership. Journal of Managerial Psychology, 17, 672-691.

Houghton, J. D., \& Yoho, S. (2005). Toward a contingency model of leadership and psychological empowerment: When should self-leadership be encouraged? Journal of Leadership and Organizational Studies, 11, 65-83.

Jesuíno, J.C. (2002). Latin Europe cluster: From south to north. Journal of World Business, 37, 81-89.

Kalyar, M., Chaudhry, S., Rafi, N., \& Kalyar, A. (2011). Effects of Self-leadership, Knowledge Management and Culture on Creativity. European Journal of Business and Management, 3, 1-11.

Kanfer, F. H. (1970). Self-regulation: Research, issues and speculations. In C. Neuringer and J.L. Michael (Eds.), Behaviour modification in clinical psychology (pp. 178-220). New York: Appleton-CenturyCrofts.

King, N. (1990). Innovation at work: The research literature. In M. A. West \& J. L. Farr (Eds.), Innovation and creativity at work: Psychological and organizational strategies (pp. 15-59). Chichester, UK: Wiley.

Locke, E. A., \& Latham, G. P. (1990). A theory of goal setting \& task performance. Prentice Hall: New Jersey. Mahoney, M. J., \& Arnkoff, D. B. (1979). Self-management: Theory, research and application. In J.P. Brady \& D. Pomerleau (Eds.), Behavioural medicine: Theory and practice (pp.75-96). Baltimore, 
MD: William Williams.

Manz, C. C. (1986). Self-Leadership: toward an expanded theory of self-influence processes in organizations. Academy of Management Review, 11, 585-600.

Manz, C. C., \& Sims, H. P. Jr. (1980). Self-management as a substitute for leadership: A social learning perspective. Academy of Management Review, 5, 361-7.

Marques-Quinteiro, P., \& Curral, L. (2012). Goal orientation and work role performance: Predicting adaptive proactive work role performance through self-leadership strategies. The Journal of Psychology, 146, 559-577.

Marques-Quinteiro, P., Curral, L. A., \& Passos, A. M. (2012). Adapting the Revised Self-leadership to the Portuguese Context. Social Indicators Research, 108, 553-564.

Masood, K., Shahzad, C., Nosheen, R., \& Awais, K. (2011). Effects of self-leadership, knowledge management and culture on creativity. European Journal of Business and Management, 3, 1-11.

Mumford, M. D., \& Gustavson, S. B. (1988). Creativity syndrome: Integration, application and innovation. Psychological Bulletin, 103, 27-43.

Neck, C. P., \& Houghton, J. D. (2006). Two decades of self-leadership theory and research: Past developments, present trends and future possibilities. Journal of Managerial Psychology, 21, 270295.

Neck, C. P., \& Manz, C. C. (1996a). Though self-leadership: The impact of mental strategies training on employee cognition, behaviour and affect. Journal of Organizational Behaviour, 17, 445-467.

Neck, C. P., Neck., H. M., Manz, C. C., \& Godwin, J. (1999). I think I can, I think I can: A self-leadership perspective toward enhancing entrepeurner thought patterns, self-efficacy and performance. Journal of Managerial Psychology, 14, 477-501.

Neck, C. P., \& Manz, C. C. (1992). Thought self-leadership: The influence of self-talk and mental imagery on performance. Journal of Organizational Behavior, 13, 681-699.

Neck, C. P., \& Manz, C.C. (1996b). Total leadership quality: integrating employee self-leadership and total quality management. In S. Goush and D. Fedor (Eds), Advances in the management of organizational quality (Vol.1, pp. 39-77). Greenwich, CT: JAI Press.

Neck, C. P., \& Manz, C. C. (2010). Mastering self-leadership: Empowering yourself for personal excellence (5th ed.). Upper Saddle River, NJ: Prentice Hall.

Needleman, J., Buerhaus, P., Mattke, S., Stewart, M., \& Zelevinsky, K. (2002). Nursing staffing levels and quality of care in hospitals. New England Journal of Medicine, 346, 1715-1722.

Pearce, C. L., \& Conger, J. A. (2003). All those years ago: The historical underprintings of shared leadership. In C.L. Pearce and J. A. Conger (Eds), Shared leadership: Reframing the hows and whys of leadership (pp.1-18). Thousand Oaks, CA: Sage.

Pearce, C. L., \& Manz, C. C. (2005). The new silver bullets of leadership: the importance of self and shared leadership in knowledge work. Organizational Dynamics, 34, 130-140.

Phelan, S., \& Young, A. M. (2003). Understanding creativity in the workplace: an examination of individual styles and training in relation to creative confidence and creative self-leadership. Journal of Creative Behaviour, 37, 266-81.

Poell, R. F., \& Van der Krogt, F. J. (2014). An empirical typology of hospital nurses' individual learning paths. Nurse Education Today, 34, 428-433.

Pratoom, K., \& Savatsomboon, G. (2010). Explaining factors affecting individual innovation: The case of producer group members in Thailand. Asia Pacific Journal of Management, 29, 1063-1087.

Prussia, G. E., Anderson, J. S., \& Manz, C. C. (1998). Self-leadership and performance outcomes: The mediating influence of self-efficacy. Journal of Organizational Behaviour, 19(5), 523-538.

Rank, J., Pace, V. L., \& Frese, M. (2004). Three avenues for future research on creativity, innovation, and initiative. Applied Psychology: An International Review, 53, 518-528.

Richer, Marie-Claire, Ritchie, J., \& Marchionni, C. (2009). “If we can't do more, let's do it differently!” Using appreciative inquire to promote innovative ideas for better health care work environments. Journal of Nursing Management, 17, 947-955.

Rousseau, D. M. (1997). Organizational behaviour in the new organizational era. Annual review of psychology, 48, 515-46.

Ryan, R. M., \& Deci, E. L. (2000). Self-determination theory and the facilitation of intrinsic motivation, social development, and well-being. The American psychologist, 55, 68-78.

Scott, S.G., \& Bruce, R.A. (1994). Determinants of innovative behaviour: a path model of individual innovation in the workplace. Academy of Management Journal, 37, 580-607.

Shalley, C., Gilson, L., \& Blum, T. (2009). Interactive effects of growth need strength, work context, and job complexity on self-reported creative performance. Academy of Management Journal, 52, 489-505.

Sheldon, K. M., Ryan, R. M., Rawsthorne, L., \& Ilardi, B. (1997). Trait self and true self: Cross-role variation 
in the big five traits and its relations with authenticity and subjective well-being. Journal of Personality and Social Psychology, 73, 1380-1393.

Smith, G. P. (2002). The new leader: Bringing creativity and innovation to the workplace. Georgia: Chart Your Course.

Stewart, G. L., Courtright, S. H., \& Manz, C. C. (2011). Self-leadership: A multilevel review. Journal of Management, 37, 185-222.

Toode, K., Routasalo, P., \& Suominen, T. (2011). Work motivation of nurses: A literature review. International Journal of Nursing Studies, 48, 246-257.

Unsworth, K. L., \& Mason, C. M. (2012). Help yourself: the mechanisms through which a self-leadership intervention influences strain. Journal of occupational health psychology, 17, 235-45.

Van de Ven, A. H., Polley, D. E., Garud, R., \& Venkataraman, S. (1999). The innovation journey. New York: Oxford University Press.

Ward, J. (1963). Hierarchical grouping to optimize an objective function. Journal of the American Statistical Association, 58, 236-244.

West, M. A., \& Anderson, N. R. (1996). Innovation in top management teams. Journal of Applied Psychology, $81,680-693$.

West, M. A. (1987). A measure of role innovation in the world of work. British Journal of Social Psychology, 26, 83-85.

West, M. A. (2002). Sparkling fountains or stagnant ponds: An integrative model of creativity and innovation in work groups. Applied Psychology: An International Review, 51, 355-386.

West, M. A., \& Farr, J. L. (1990). Innovation and creativity at work: Psychological and organizational strategies. Chichester: John Wiley.

West, M. A., Borrill, C. S., Dawson, J. F., Brodbeck, F., Shapiro, D. A., \& Haward, B. (2003). Leadership clarity and team innovation in health care. The Leadership Quarterly, 14, 393-410.

West, M. A., Sacramento, C. A., Fay, D. (2006). Creativity and innovation implementation in work groups: The paradoxical role of demands. In L. Thompson and H. S. Choi (Eds.), Creativity and Innovation in Organizational Teams. USA: Lawrence Erlbaum Associates, Inc..

World Health Organization 2000. The World report 2000. Health systems: Improving performance [PDF]. Retrieved from http://www.who.int/whr/2000/en/whr00_en.pdf

Xerri, M. (2012). Workplace relationships and the innovative behaviour of nursing employees: A social exchange perspective. Asia Pacific Journal of Human Resources, 5, 103-123.

Zimmerman, B. J. (2008). Investigating Self-Regulation and Motivation: Historical Background, Methodological Developments, and Future Prospects. American Educational Research Journal, 45, 166-183.

Historial do artigo

Recebido 03/02/2015

Aceite 27/03/2015

Publicado 06/2015

Apoio à publicação: Fundação para a Ciência e a Tecnologia (Ministério da Educação e Ciência, Portugal) - Programa FACC 